\title{
Study on the sensory score of fresh and after storage in cultured chhana whey soft drink
}

\author{
Devesh Gupta
}

\begin{abstract}
The present study was to know the consumer acceptability of sensory score of fresh and after storage for 1 day, 2 day and 3 days at $5^{\circ} \mathrm{C}$ in cultured whey soft drink of flavour like orange, mango and pineapple with orange, red and yellow colour, respectively used. It can be concluded from that among the different flavour drink pine apple flavor was highly preferred.
\end{abstract}

KEY WORDS : Whey, Whey drink

HOW TO CITE THIS PAPER : Gupta, Devesh (2019). Study on the sensory score of fresh and after storage in cultured chhana whey soft drink. Res. J. Animal Hus. \& Dairy Sci., 10(2) : 63-64 : DOI: 10.15740/HAS/RJAHDS/10.2/63-64. Copyright@ 2019: Hind Agri-Horticultural Society. 